\title{
DISEASES OF THE RESPIRATORY SYSTEM WITH THE SUBSEQUENT FORMATION OF CARDIOVASCULAR PATHOLOGY IN CHILDREN
}

\author{
Gonchar M. ${ }^{1}$, Ishenko T. ${ }^{1}$, Buginskaya N. ${ }^{1}$, Orlova N. ${ }^{1}$, Kuznetsova D. ${ }^{1}$, \\ Saienko V. ${ }^{1}$, Pushkar O. ${ }^{2}$, Kriganovskaya O. $^{2}$ \\ Kharkiv National Medical University ${ }^{1}$, \\ Kharkiv Regional Children's Clinical Hospital ${ }^{2}$
}

\begin{abstract}
Diseases of the respiratory system are one of the most frequent causes of the treatment of children in hospital facilities. The younger the child, the more often these diseases occur and the more severe it can be. Cardiovascular disorders with bronchopulmonary pathology develop slowly, potentially reversible in childhood, which requires a correct assessment of the risk of their development for a particular patient and timely correction of therapy. The presence of dyspnea, prolonged exhalation, pale skin, cyanosis of the nasolabial triangle and acrocyanosis, swelling of the nose (symptoms common to cardiac and respiratory failure) indicate the reaction of the cardiovascular system in diseases of the respiratory system. We examined 14 children: among them 7 boys and 7 girls. Ten children were diagnosed with acute obstructive bronchitis, and 4 with pneumonia. In the course of the study, the parameters were assessed, reflecting the linear dimensions of the heart cavity and the main vessels, followed by the calculation of central hemodynamics, diastolic transmittal blood flow by the method of L.K. Hattle, B. Angelsen.
\end{abstract}

Key words: bronchopulmonary pathology, children, electrocardiography, doppler echocardiography of the heart.

Introduction. Respiratory diseases are one of the most common causes for the treatment of children in hospitals. The younger the child, the higher the incidence of these diseases and the more severe it may develop [1, 2]. Cardiovascular disorders in broncho-pulmonary pathology develop slowly, are potentially reversible in childhood, requiring a proper assessment of the risk of their development for a particular patient and timely correction of therapy tactics [3].

Toxicosis, as well as frequent concomitant diseases and oxygen deficiency cause profound changes in tissue metabolism, decrease in the processes of energy formation, disturbance of the regulatory function of central and autonomic nervous systems. All these factors affect the activity of the heart and the circulatory system as a whole, developing both compensatory, adaptive and pathological reactions [4].

Corresponding Author:

Tatiana Ishenko, MD, PhD, Associate Professor, Department of Pediatrics 1 and Neonatology,

Kharkiv National Medical University, Ukraine.

E-mail:7tanyatb7@gmail.com
The reaction of the cardiovascular system in diseases of the respiratory system is characterized by dyspnea, prolonged vision, pallor of the skin, cyanosis of the nasolabial triangle and acrocyanosis, inflammation of the nasal wings, a decrease in the ratio of respiratory and pulse rates [5], tachycardia that does not correspond to body temperature, accent of tone 2over the pulmonary artery, muffling of the tone of the heart, systolic murmur of soft tone (general symptoms of cardiac and respiratory failure) [6].

Assessment of literature data showed that bronchopulmonary diseases, which begin their pathological path in early childhood, may lead to irreversible changes in adults with the development of complications and early mortality $[7,8]$. Thus, children with frequent respiratory diseases may potentially replenish the population of adults with chronic obstructive pulmonary diseases, which is a very significant problem, requiring a combination of efforts of different specialists [9, 10].

2. Purposes, subjects and methods:

2.1. Purpose - to study the development of cardiovascular disorders in children from 1 month to 3 years with bronchopulmonary disorders. 
2.2. Subjects \& Methods. The research was carried out at the Department of Pediatrics No.1 and Neonatology of KhNMU, at the Department of Infectious Diseases of Kharkiv Regional Children's Clinical Hospital. The study implied the assessment of histories, clinical and instrumental data. The features of bioelectric activity of the heart in the examined children were assessed by the results of electrocardiography. In the course of the study, we evaluated the indices reflecting the linear dimensions of the cardiac cavity and major vessels with subsequent calculation of central hemodynamics, diastolic transdermal blood flow by the method of L.K. Hattle and B. Angelsen following Doppler echocardiography of the heart ("AU 3 Partner" by "Esaote Biomedica" (Italy).

Conflict of interests. There is no conflict of interests.

3. Results and discussion. We examined 78 children aged from 1 month to 3 years, who were divided into 3 groups: Group 1 included 28 (35.8\%) children with acute obstructive bronchitis and pneumonia, Group 2 comprised 27 children (34.6\%) with acute simple bronchitis, Group 3 was the control group of 23 children (29.6\% of healthy children). The average age of children was $1.5 \pm 1.6$ years. The groups were representative and comparable by gender and age.

Assessment of family histories showed that most children (75 \%) were the first child in the family. First-degree relatives of $28.6 \%$ children had cardiovascular disorders, namely arterial hypertension. Mothers of $37.5 \%$ children had pains or discomfort in the area of the heart on exertion and stress, which resolved spontaneously or after taking sedative.

Parents of $62.5 \%$ children were overweight, due to insufficient motor and sedentary lifestyles. During pregnancy mothers of $87.5 \%$ children were examined for TORCH infections, of whom $50 \%$ were infected with herpes virus or rubella. Parents of $62.5 \%$ children often drank alcohol or low-alcohol beverages; fathers of $87.5 \%$ smoked, and both parents of $25 \%$ smoked. Mothers of $12.5 \%$ children have focal points of chronic infection (chronic tonsillitis).

Assessment of children and their relatives' complaints on admission showed the following data. Cough and dyspnea were observed in all children. In this case, $75 \%$ of mothers described the cough as dry or non-productive. Elevated body temperature was observed in $87.5 \%$ of children. Besides, $62.5 \%$ of children had nasal congestion or mucous discharge from the nose, and $50 \%$ had distant wheezing. Features of bioelectric activity of the heart in the examined children were determined by ECG.

There were 8 (12\%) patients with no ECG changes.

In other $88 \%$, morphological and functional features were registered. The violation of ventricular myocardial repolarization was prevalent in $73.8 \%$, and nomotonic rhythm disturbances in the form of sinus tachycardia in $40.5 \%$. Also, overload and hypertrophy of the right chambers of the heart were observed in $18 \%$ and a decrease in bioelectric activity of the heart (voltage) in $14.3 \%$.

The control group children were also found to have a significant difference in numbers. Thus, violation of ventricular myocardial repolarization and nomotonic rhythm disturbances in the form of sinus tachycardia occurred much less commonly, in 14 and $19 \%$ respectively. And such changes as overload and hypertrophy of the right chambers of the heart and a decrease in bioelectric activity of the heart were not recorded at all.

The study of morphology of the heart, functional state of the myocardium and indices of central hemodynamics implied an assessment of Doppler echocardiography findings. Doppler echocardiography (DopECHOCG) of the heart showed an increase in mean pressure on the pulmonary artery (PA) to $20 \mathrm{mmHg}(63 \%)$, which significantly exceeded the norm $(\mathrm{p}<0.05)$ in comparison with the control group, 1st degree regurgitation of the tricuspid valve (14\%) and $1^{\text {st }}-2^{\text {nd }}$ degree of the PA valve (23\%), which was significantly increased in comparison with the control group $(\partial<0.05)$; an increase in the diameter of the right atrium and right ventricle (30\%), which significantly differed in patients of the control group $(p<0.05)$. Mild structural anomalies of the heart were recorded with the same frequency and the rates did not exceed the average incidence in the population.

A comprehensive cardiac examination using ECG, Doppler echocardiography of the heart made it possible to detect early changes in the cardiovascular system in the form of sinus tachycardia, an increase in average pressure on the airway, an increase in the diameter of the right atrium and right ventricle, etc. Acute inflammatory process in the respiratory tract is accompanied by disturbances of microcirculation, which in turn can lead to systemic disruption of the functioning of the whole organism. But most often it affects the cardiovascular system. 
4. Conclusions. In order to prevent the development of cardiovascular complications in the cardiovascular system in young children, it's necessary to provide:

- timely detection and appropriate treatment for children with acute broncho-pulmonary pathology;
- dynamic monitoring with ECG and DopECHOCG.

These data should be taken into account when monitoring children to identify the risk group for the development of cardiovascular complications with possible administration of antihypoxic agents.

\section{References:}

1. Katilov A.V. (2014). Klinicheskaja pul'monologija detskogo vozrasta. [Clinical pulmonology of childhood]. Vinnica, vtoroe izdanie, s. 255.

2. Volkov I.K. (2013). Differencial'naja diagnostika bronhoobstruktivnogo sindroma u detej. [Differential diagnostics of broncho-obstructive syndrome in children]. Medicina neotlozhnyh sostojanij ${ }^{1} 1$ (48), s. $125-128$.

3. Senatorova A.S. (2011). Vtorichnye kardiomiopatii. [Secondary cardiomyopathy]. Har'kov, s. 342.

4. Noraga M.V. (2007). Postgipoksicheskaja disfunkcija serdechno-sosudistoj sistemy u novorozhdennyh detej. [Postgiplexic dysfunction of the cardiovascular system in newborn babies]. Voprosy sovremennoj pediatrii, T. $3{ }^{1} \quad 3$, s. 42-46.

5. Klimenko T.M. (2011). Novoe v definicii patogeneza bronholegochnoj displazii u novorozhdennyh. [New in defining the pathogenesis of bronchopulmonary dysplasia in newborns]. Zdorov'e rebenka, 11 (28), s. $115-120$.

6. Fanaroff À.À. (2007) Trends in neonatal morbidity and mortality for very low birthweight infants. Am. J. Obstet. Gynecol, ${ }^{1} 196$ (2), ð. 1-8.

7. Prahov A.V. (2008). Vnutriserdechnoe krovoobrashhenie u nedonoshennyh detej s tjazhelym perinatal'nym porazheniem CNS i sindromom dyhatel'nyh rasstrojstv. [Intracircular circulation in preterm infants with severe perinatal central nervous system and respiratory distress syndrome]. Pediatrija (zhurnal imeni Speranskogo), T. 87, 1 1, s. 28-31.

8. Ovsjannikov D.Ju. (2014). Bronhoobstruktivnyj sindrom u detej. [Broncho-obstructive syndrome in children]. Astma i alerg3ja 1, s. 13-17.

9. Solov'eva N.A. (2014). Bronhoobstruktivnyj sindrom u detej rannego vozrasta. [Bronchoobstructive syndrome in young children]. Pediatricheskij zhurnal 4, s. 33-37.

10. Susannah Fleming, Matthew Thompson, Richard Stevens (2011). Normal ranges of heart rate and respiratory rate in children from birth to 18 years: a systematic review of observational studies. Lancet. doi:10.1016/S0140-6736(10)62226-X.

Received: 17-Jul. - 2018

Accepted: 08-Sep. - 2018 